\title{
Managemen dan Pelayanan Medis pada Kambing Milik Masyarakat di Desa Seureumo Kecamatan Indrapuri Aceh Besar
}

\author{
Daniel $^{1{ }^{* *}}$, Dedhi Yustendi ${ }^{1)}$, Mulyadi $^{1}$, Zahrul Fuadi $^{1}$, Sari Wardani ${ }^{1}$, Fawwaraly $^{1}$, Savitri $^{2}{ }^{2}$ \\ Elvrida Rosa ${ }^{2}$ \\ ${ }^{1}$ Prodi Peternakan Universitas Abulyatama \\ ${ }^{2}$ Prodi Agroteknologi Universitas Abulyatama \\ ${ }^{1 *}$ Email : daniel.mustafa@ rocketmail.com
}

\begin{abstract}
ABSTRAK
Ternak kambing yang dilakukan oleh masyarakat desa masih sangat tradisional dan semi intensif padahal ternak kambing memiliki potensi yang cukup besar untuk diternakkan dan dikembangkan. Kondisi pemeliharaan ini harus menjadi perhatian untuk mensugesti dan menambah pengetahuan masyarakat sehingga dapat mengubah pola pikir dan mendesain kembali konsep bisnis peternakan untuk menghasilkan produk unggulan di masa yang akan datang. kegiatan yang dilakukan adalah melakukan sosialisasi langsung oleh Dosen Peternakan Universitas Abulyatama Aceh tentang cara beternak yang baik, pemberian pakan yang ideal, managemen pembibitan dan evaluasi bisnis peternakan. Managemen kesehatan baik berupa pencegahan mapun penanganan penyakit ternak diaplikasi langsung pada ternak oleh dosen dan mahasiswa. Hasil kegiatan menunjukkan sosialisasi pemberian pakan dan penanganan penyakit parasit menjadi hal yang utama yang harus dilakukan dalam upaya meningkatkan produktifitas ternak.
\end{abstract}

Kata Kunci: Kambing, Seureumo, Peternakan, kesehatan

\begin{abstract}
Goats carried out by the village community are still very traditional and semiintensive, even though goats have a large potential to be raised and developed. This maintenance condition must be a concern to suggest and increase public knowledge so that it can change the mindset and redesign the livestock business concept to produce superior products in the future. The activities carried out were direct socialization by Lecturers of Livestock at the University of Abulyatama Aceh about good farming practices, ideal feeding, nursery management and evaluation of the livestock business. Health management in the form of prevention and handling of livestock diseases is applied directly to livestock by lecturers and students. The results of the activity show that socialization of feeding and handling of parasitic diseases is the main thing that must be done in an effort to increase livestock productivity.
\end{abstract}

Keyword : Goat, Seureumo, Ranch, health. 
BAKTIMAS

Jurnal Pengabdian pada Masyarakat
Vol. 3, No. 2,

Juni 2021
eISSN 2685-113x

pISSN 2685-0303

\section{PENDAHULUAN}

Kambing merupakan ruminansia kecil yang memiliki potensi yang cukup besar untuk diternakkan dan dikembangkan, hal ini dikarenakan kambing memiliki beberapa keuntungan diantaranya adalah mudah beradaptasi dengan lingkungan, membutuhkan modal yang tidak terlalu besar, serta pemeliharaanya yang relatif mudah. Di Indonesia kambing dimamfaatkan sebagai sumber produk hewani yang diambil daging dan susunya. (Pamungkas dkk., 2008)

Desa Seureumo merupakan salah satu desa di Indrapuri yang memiliki potensi dalam pengembangan kambing, hal ini dinilai dari banyaknya minat masyarakat yang memelihara kambing baik sebagai usaha sampingan maupun usaha utama. Managemen pemeliharaan yang dilakukan oleh peternak desa tersebut masih sangat tradisional dan semi intensif dimana masyarakat menghabiskan waktu yang relatif panjang untuk memotong rumput setiap harinya padahal hasil kajian menunjukkan bahwa rumput yang tumbuh di daerah tropis mayoritas bermutu rendah dengan serat kasar yang tinggi, sementara untuk penanaman rumput unggul seperti rumput gajah dan sebagainya terkendala terbatasnya lahan sehingga diperlukan pakan tambahan untuk mencukupi nutrisi ternak kambing. Managemen kesehatan yang dilakukan adalah dengan memanggil tenaga kesehatan hewan pada saat ternak menderita penyakit tanpa melakukan proses pegendalian/pencegahan ataupun pemberian vitamin yang mampu meningkatkan produktivitas kambing.

Kondisi pemeliharaan ini harus menjadi perhatian oleh berbagai pihak terutama tenaga akademisi di Universitas yang membidangi bidang peternakan yang secara keilmuan mampu untuk mensugesti dan menambah pengetahuan masyarakat sehingga dapat mengubah pola pikir dan mendesain kembali konsep bisnis peternakan untuk menghasilkan produk unggulan di masa yang akan datang.

\section{METODE}

Kegiatan yang dilakukan adalah kombinasi antara tim dosen, mahasiswa dan masyarakat. Dosen sebagai sumber informasi, mahasiswa sebagai eksekutor lapangan dan peternak sebagai penerima mamfaat, kegiatan ini diharapkan menjadi kegiatan pendahuluan yang nantinya mampu dilanjutkan oleh peternak secara kontinue sehingga memberikan efek besar dalam peternakan yang dikelolanya. Adapun tahapan pelaksanaan meliputi :

1. Managemen Peternakan

Kegiatan ini dilakukan dengan melakukan sosialisasi cara beternak yang baik, pemberian pakan yang ideal, managemen pembibitan dan evaluasi bisnis peternakan oleh Dosen Peternakan Universitas Abulyatama Aceh.

2. Managemen Kesehatan

Kegiatan ini dilakukan dengan melakukan diagnosa dan penanganan medis secara langsung pada ternak-ternak yang sakit, serta melakukan pemberian vitamin untuk menjaga kesehatan. 
Daniel, dkk.

\section{HASIL DAN PEMBAHASAN}

Hasil kegiatan menunjukkan sistem pemeliharaan kambing masih dilakukan secara tradisional dan semi intensif dimana masyarakat menghabiskan waktu yang relatif panjang untuk memotong rumput setiap harinya. Perkandangan sudah mulai semi intesif, masyarakat sudah memiliki kandang panggung dan pemilihan bibit sudah sangat baik dengan mengandalkan pengalaman pemeliharaan yang sudah bertahun tahun. Pemberian pakan dilakukan dengan pemberian rumput, Kondisi ini menjadi fokus sosialisasi dan evaluasi agar masyarakat menambah pakan-pakan penguat sebagai sumber nutrisi tambahan sehingga peternakan menjadi lebih baik dimasa yang akan datang.

Kambing-kambing yang dipelihara masyarakat dalam kondisi kesehatan yang relatif sehat. Mayoritas penyakit yang di tangani adalah penyakit parasit baik intena maupun eksterna berupa helminthiasis dan scabiosis, dan penyakit -penyakit yang lain seperti Orf, Salmonellosis, Tympani dan Hypocalsemia dengan angka yang lebih kecil seperti terlihat pada Gambar 1.

PENYAKITYANG DITANGANI

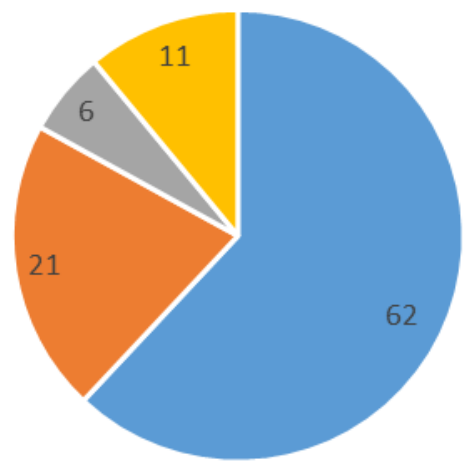

- Parasit $\quad$ Virus $\quad$ Bakteri = Lain Lain

Gambar 1. Penyakit yang ditangani didalam kegiatan (Persen)

Dari Gambar terlihat bahwa penyakit parasit merupakan penyakit terbanyak mencapai 62 pesen. Penyakit parasit adalah penyakit yang disebabkan oleh organisme yang hidup sementara ataupun tetap di dalam atau pada permukaan organisme lain (Sandjaja, 2007). Infeksi parasit ini menimbulkan kerugian yang sangat besar pada ternak. Hal ini disebabkan parasit menyerap zat-zat makanan, menghisap darah/cairan tubuh, atau makan jaringan tubuh ternak. Parasit juga menyebabkan kerusakan pada sel-sel epitel usus, sehingga dapat menurunkan kemampuan usus dalam proses pencernaan dan penyerapan zat- zat makanan serta produksi enzim-enzim yang berperan dalam proses pencernaan. Selain itu berkumpulnya parasit dalam jumlah besar di usus atau lambung ternak dapat menyebabkan penyumbatan atau obstruksi sehingga proses pencernaan makanan terganggu (Saputra dkk., 2019). 
BAKTIMAS

Jurnal Pengabdian pada Masyarakat
Vol. 3, No. 2,

Juni 2021
eISSN 2685-113x

pISSN 2685-0303

Penanganan penyakit ini dilakukan dengan menggunakan antiparasit spectrum luas yang dilakukan oleh dosen dan mahasiswa (Gambar 2), serta dilakukuan juga upaya sosialisasi untuk penegendalian penyakit parasit seperti sistem pemeliharaan, pemotongan rumput yang terlalu pagi, sanitasi dan kebersihan kandang. (Tolistiawaty dkk., 2016).
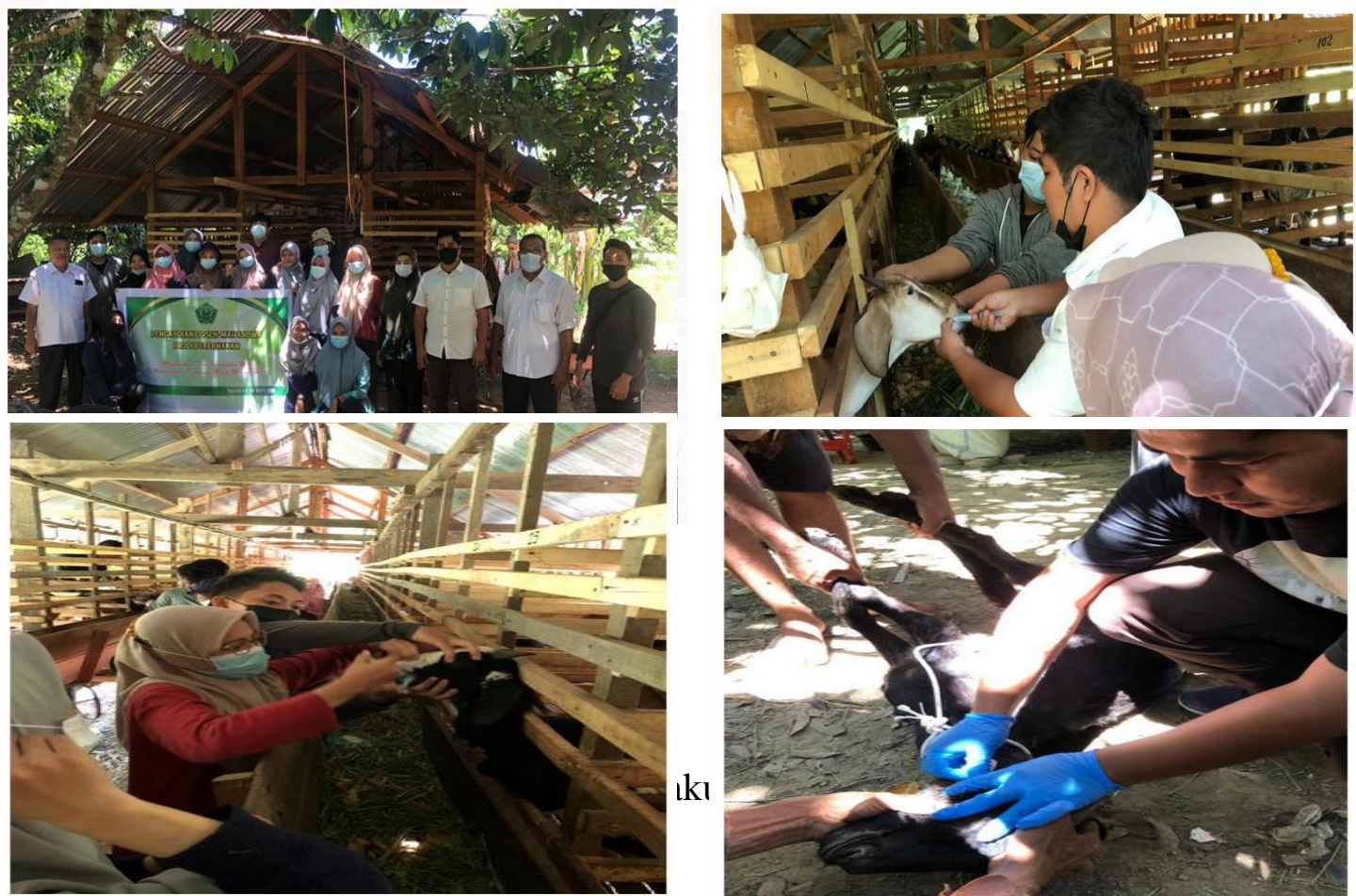

1. Managemen pakan menjadi hal yang paling penting didalam sosialisai kepada masyarakat desa Seureumo, Kecamatan Indrapuri Aceh Besar.

2. Mayoritas ternak kambing menderita penyakit parasite.

\section{UCAPAN TERIMA KASIH}

Ucapan terima kasih kami sampaikan kepada pimpinan Universitas Abulyatama, Pimpinan Fakultas Pertanian Abulyatama, LPPM, Aparatur Desa Seureumo, Dosen- dosen yang telibat, masyarakat dan peternak di wilayah desa serta mahasiswa.

\section{DAFTAR PUSTAKA}

Pamungkas. F. A., F. Mahmilia, S. Elieser, (2008). Perbandingan Karakteristik Semen Kambing Boer Dengan Kacang. Seminar Nasional Teknologi Peternakan dan Veteriner. Sumatera Utara.

Sandjaja, B. (2007). Parasitologi Kedokteran. Jakarta: Prestasi Pustaka Publisher. Schad,

Saputra, H. M., M. R. D. Putra. (2019). Jenis-Jenis Parasit Internal Pada Feses Kambing (Capra sp.) Di Pasar Kambing Kota Bengkulu. Jurnal Konservasi Hayati $10(2), 56-63$ 
Daniel, dkk.

Tolistyawaty I, J. Widjaja, L. T. Lobo, R. Isnawati. (2016). Parasit Gastrointestinal

Pada Hewan Ternak di Tempat Pemotongan Hewan, Kabupaten Sigi, Sulawesi Tengah. Balaba. Vol 12 (2), 71-78. 